\title{
Comparing the $\mathrm{CO} 2$ emission by kilogram transported in normal flight and in a clear air turbulence area
}

Air transport contributes with $2 \%$ of global emission to greenhouse effect. This situation aggravates the occurrence of meteorological phenomenon of Clear Air Turbulence (CAT). When an aircraft flies over a CAT area they increase the fuel consumption to adequate the speed and lift. Consuming more fuel aggravates the greenhouse effect. The objective of this paper is to quantify the emission of pollutants in the atmosphere, through the application of a conceptual and dynamic decision model for microscopic analysis of air traffic flow. The method consists of delimiting the CAT area, staggering flight parameters, and calculating CO2 emissions in normal conditions and with CAT. When there is CAT, there are two options: proceed in the same flight plan or make a route deviation to a lowe altitude. The comparison between the conditions of flights with the presence of CAT, infers that changes to a lower altitude during the flights is viable, because there is a reduction in fuel consumption and hence in $\mathrm{CO} 2$ emissions.

Keywords: Clear Air Turbulence Area; CO2 Emission; Global Emission.

\section{Comparação da emissão de CO2 por quilograma transportado em voo normal e em área de turbulência de ar limpo}

O transporte aéreo contribui com $2 \%$ da emissão global para efeito estufa. Esta situação agrava a ocorrência de fenômenos meteorológicos de turbulência de Clear Air (CAT). Quando uma aeronave voa sobre uma área de CAT, aumenta o consumo de combustível para adequar a velocidade e a sustentação. Consumir mais combustível agrava o efeito estufa. O objetivo deste trabalho é quantificar a emissão de poluentes na atmosfera, por meio da aplicação de um modelo conceitual e dinâmico de decisão para análise microscópica do fluxo de tráfego aéreo. O método consiste em delimitar a área CAT, escalonar os parâmetros de voo e calcular as emissões de $\mathrm{CO} 2$ em condições normais e com CAT. Quando há CAT, há duas opções: prosseguir no mesmo plano de voo ou fazer um desvio de rota para uma altitude menor. A comparação entre as condições dos vôos com a presença de CAT, infere que a mudança para uma altitude menor durante os vôos é viável, pois há uma redução no consumo de combustível e, consequentemente, nas emissões de $\mathrm{CO} 2$

Palavras-chave: Área de turbulência de ar limpo; Emissão de CO2; Emissão Global.

Topic: Sustentabilidade nos Transportes

Reviewed anonymously in the process of blind peer.
Received: 10/06/2018

Approved: $24 / 07 / 2018$
Reinaldo Moreira Del Fiaco (D)

Instituto Militar de Engenharia, Brasil

http://lattes.cnpq.br/3953285578906686

http://orcid.org/0000-0001-6475-1426

fiaco@ime.eb.br

Flávio Vieira da Silva Júnior (iD

Instituto Militar de Engenharia, Brasil

http://lattes.cnpq.br/2211436659738090

http://orcid.org/0000-0002-7344-4679

flaviovisiju@gmail.com

Camila Maestrelli Leobons

Instituto Militar de Engenharia, Brasil

http://lattes.cnpq.br/6690447554849706

http://orcid.org/0000-0001-8303-2793

camila@maestrelli.org

\author{
Marcelo Miranda Reis \\ Instituto Militar de Engenharia, Brasi \\ http://lattes.cnpq.br/0498662991287399 \\ http://orcid.org/0000-0003-3875-9189 \\ marcelorei@ime.eb.br
}

Referencing this:

DEL FIACO, R. M.; SILVA JÚNIOR, F. V.; LEOBONS, C. M.; REIS, M. M.. Comparing the $\mathrm{CO} 2$ emission by kilogram transported in normal flight and in a clear air turbulence area. Revista Ibero Americana de Ciências Ambientais, v.9, n.5, p.133-145, 2018. DOI: http://doi.org/10.6008/CBPC2179-6858.2018.005.0013

DOI: 10.6008/CBPC2179-6858.2018.005.0013 


\section{INTRODUCTION}

Turbulence is a modification in the mass of air of mechanical nature, a vertical mixture (fluctuations) of the wind flow that affects the aerodynamics of the airplanes. As a consequence, the encounter of the aircraft with turbulence generates changes of altitude, corrections in the commands of flight, disturbances in the flow of air traffic, increase in the consumption of fuel, and causes discomfort to the crew and passengers (COOPER et al., 2004).

Even with the advancement of technologies for weather and resource for climatological databases, some meteorological phenomena are often imperceptible. Clear Air Turbulence (CAT) is an example of an 'imperceptible' phenomenon, and its occurrences are often reported by Airline Pilots. The natural phenomenon of CAT is aggravated by climate changes (WILLIAMS et al., 2013). Aeronautical Meteorology is a field of applied meteorology to the studies of the characteristics of atmospheric phenomena for low and high altitudes. These studies aim to find a balance between economy and flight safety (COOPER et al., 2004).

Lyons, Panofsky, Wollaston (1964) was the first to research the instability of the air regarding the conditions of lift of the aircraft. FAA (2004) studied the impacts of aviation on the environment and showed that as technologies in engines, aerodynamics and control of airspace advances it reduces fuel consumption. ICAO (2011) with the intention of comparing the evolution of aircraft engines with the number of passengers transported, developed a methodology for quantifying fuel consumption per Available Seat per Kilometer (ASK).

Williams (2017) studied how Clear Air Turbulence through the analysis of gravitational waves and the number of Richardson affects the aerodynamics of the aircraft. The influence of turbulence conditions on flights in the Midwest region of Brazil was studied by Barros et al. (2013). Fiaco et al. (2016) identified the areas with the highest prognosis of Clear Air Turbulence in Brazil and developed a dynamic model for traffic flow analysis for flights in turbulent conditions.

The aviation industry has consistently implemented environmental performance improvements. However, these continuous technological improvements have not accompanied the increase in emissions due to the growth of air traffic, as emissions improvements grow $3 \%$ per annum while air traffic increases between 4-5\% per year (CAOA, et. al, 2016; FAA, 2017). This growth of the aviation industry brings many benefits, but also comes with negative impacts to the environment such as the emission of substances from the aircraft. According to Caoa et. al (2016), since 2002 emissions growth is forecast to double over a period of 23 years.

The main objective of this article is to quantify the increase of the $\mathrm{CO} 2$ production of aircraft when passing through areas of Clear Air Turbulence. For this it was quantified the increase in fuel consumption generated by passing through clear air turbulence areas, as well as in an alternative wherein the aircraft deviates from its route to avoid the CAT. 


\section{THEORETICAL REVIEW}

\section{Clear Air Turbulence}

Clear air turbulence (CAT) occurs in the absence of rain clouds that indicate precipitation, so-called cumuliform clouds, however other clouds are associated with CAT, such as cirrocumulus and cirrus uncinus (COOPER et al., 2004). Cirrus clouds indicates cold fronts, have a silky or fibrous shape, bright color and announce medium to strong winds. The cirrocumulus clouds have a thin, granular and wrinkled shape. Both are one of the possible baseline indicators of the jet stream and Clear Air Turbulence (BARROS et al., 2013).

In Brazil, jet streams are common in winter and it is at this time that there is an increase in occurrences of Light Sky Turbulence mainly in the South and Southeast (BARROS et al., 2013). CAT has a thickness between 3,000 ft and 6,000 ft, and occurs between FL 200 and FL 400 (read Flight Level 200 and Flight Level 400, which corresponds to $20.000 \mathrm{ft}$ and $40.000 \mathrm{ft}$ ). And it is between these altitudes that occur most commercial flights (BARROS et al., 2013).

On the boundary of the Troposphere with the Tropopause, the jet streams are found, caused by large variations in pressure from the West, independent of the hemisphere, and occur on polar and temperate latitudes. In the jet streams CAT occurs, in which the wind flows are divided into two 'branches' causing the turbulence with changes in the speed, angle and altitude of the aircraft (WILLIAMS et al., 2013).

The turbulences are instantaneous and irregular, and hardly indicate what will happen. The variations in speed and altitude caused by turbulence differ by the size and weight of the aircraft. The degree of turbulence depends on variations in the Indicated Air Speed (BARROS et al., 2013; WILLIAMS, 2017). Light turbulence causes variations between 5 and $15 \mathrm{kt}$ (knot), moderate turbulence of 15 to $25 \mathrm{kt}$ and strong turbulence above $25 \mathrm{kt}$ (WILLIAMS et al., 2013).

Figure 1 shows a clipping of a SIGWX Phenomenon Prediction Chart, a Mercator projection chart using as DATUM line the WGS84 World Geodetic System (SDOP, 2014). This chart is a template SWH - FL 250630 (Read Flight Level 250 and Flight Level 630, which corresponds to $25.000 \mathrm{ft}$ and $63.000 \mathrm{ft}$ ). The stem, line with flag, burrs and half burr is indicative of the jet stream, the stem shows an arrow with the direction of the wind. Each flag corresponds to $50 \mathrm{kt}$; burr, $10 \mathrm{kt}$; and half burr, $5 \mathrm{kt}$.

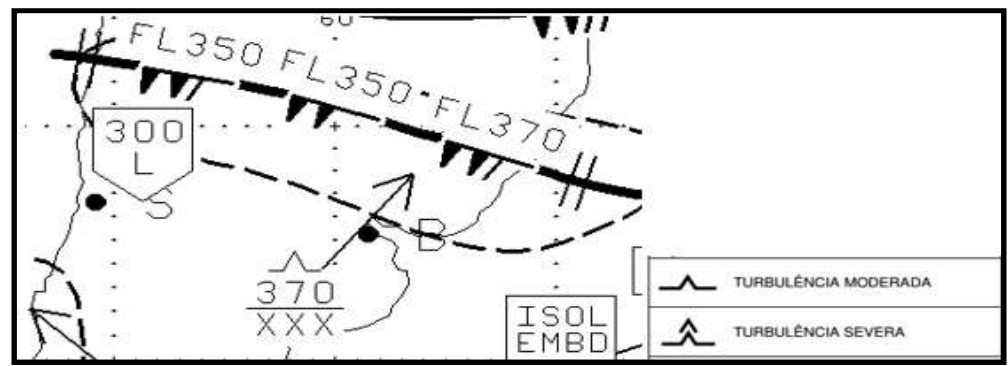

Figure 1: Example of CAT in SIGWX VALID 00 UTC 17 MAY 2010. Fonte: Redemet (2011).

The blinking line following the jet stream line is the Clear Air Turbulence area boundary (Figure 1), it is in the low-pressure areas where turbulence is predicted. At the tip of the arrow are the minimum and maximum flight altitude limits where turbulence is predicted. The XXX indication represents a layer outside 
the minimum altitude (denominator) or maximum (numerator) in which the letter refers (COOPER et al., 2004).

According to Fiaco et al., (2016), the number of occurrences of clear sky turbulence in the years 2010 to 2013 are respectively: 77; 104; 104; 125. This shows the increase in the number of occurrences over the years. Figure 2 shows the graph of occurrences of Clear Air Turbulence divided into 4 time peaks, they are: 0h; $6 \mathrm{~h} ; 12 \mathrm{~h} ; 18 \mathrm{~h}$. The times are in Zulu time, which corresponds to the time in the Greenwich meridian in Brazil (-3h). It is common that in the hour of $12 \mathrm{~h}$ there is an increase in the occurrence of the CAT, justified by the heating of the air by the irradiation of the sun, causing the reduction of the density of the air.

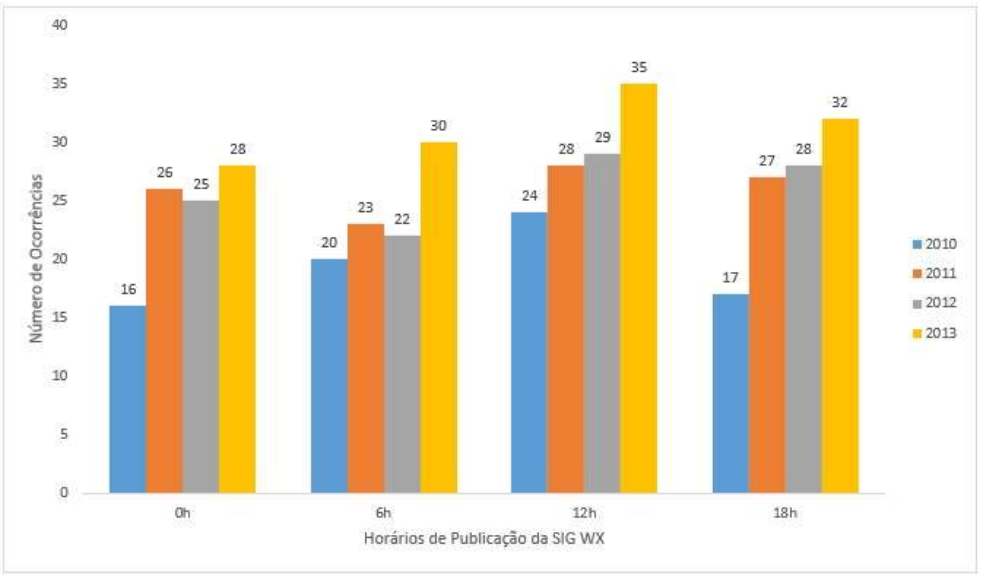

Figure 2: Prognosis of Occurrence of Light Sky Turbulence by Validity. Adapted from Fiaco et al. (2016).

Table 1 shows the total number of occurrences of CAT during the years 2010 to 2013, the average maximum and minimum altitude and total number of days occurring during the months of May to September of the years analyzed. The peak of the number of predictions of the occurrence of CAT occurs in June, on average with 110 prognoses. The table shows that the minimum altitude of occurrence of CAT is in FL 275, and maximum in FL 394.

Table 1: Quantification of Prognosis of Occurrences of Light Sky Turbulence 2010 to 2013.

\begin{tabular}{|l|l|l|l|l|}
\hline Date & $\begin{array}{l}\text { CAT Occurrence } \\
\text { Quantity }\end{array}$ & $\begin{array}{l}\text { CAT's Minimum Altitude of } \\
\text { Occurrence }\end{array}$ & $\begin{array}{l}\text { CAT Maximum Altitude of } \\
\text { Occurrence }\end{array}$ & $\begin{array}{l}\text { Number of CAT } \\
\text { Occurrence Days }\end{array}$ \\
\hline May & 86 & 287,5 & 417,5 & 47 \\
\hline Jun & 110 & 273,75 & 411,25 & 60 \\
\hline Jul & 97 & 275 & 393,75 & 46 \\
\hline Aug & 67 & 261,25 & 393,75 & 35 \\
\hline Sept & 50 & 291,25 & 391,25 & 35 \\
\hline $\begin{array}{l}\text { Total } \\
\text { Average }\end{array}$ & 410 & 275 & 393,75 & 223 \\
\hline
\end{tabular}

Source: Adapted from Fiaco et al. (2016).

Synoptic meteorology uses the process of comparison to obtain a synthesis of the results of the reading of satellite images and of information provided by the meteorological network. Based on the observation meteorologists and pilots are able to identify the evolution of fronts and wind currents (TALAIA et al, 2009). Pritchett, et. al (2003) presents two models for the analysis of meteorological information: a Forecast Model that provides a first appreciation of the atmosphere; and a Retrospective Analysis Model that provides information about the current operation of the system. The information collected from both models 
are refined in projects and better numerical models predictive of Clear Air Turbulence (COOPER AND PHILLIPS, 2004).

The main cause for buoyancy and instability of the air mass is known as Kenvin-Helmholtz Instability (KHI), whereupon air mass pressures form a single vector surface. When two surfaces of different vectors are forming a movement relative to the wind current, the consequence is the shear flow of the air masses. The result of shear air masses in the troposphere and tropopause, and parallel to the jet stream is characterized as Light Sky Turbulence (LYONS et al, 1964; WILLIANS, 2017).

The Richardson Number is a ratio created to establish the buoyancy index between the jet streams and is measured by the Brunt-Väisälä Frequency in which the Richardson number will always be a positive number (McCann, [s.d.]). The Brunt-Väisälä Frequency is the gravitational unit of atmospheric waves, in which the force of the acceleration of gravity is divided by the vertical gradient of the potential temperature (LYONS et al, 1964).

For the influence of CAT in flights it is worked with the premise that the buoyancy between the currents of the air masses will always be positive, even when there are low expectations for altitude turbulence and / or Clear Air Turbulence, and will always be a number between 10 to 0,1 indicating the presence of turbulence (COOPER et al, 2004).

$$
R i=\frac{\frac{g \partial \theta}{\theta \partial z}}{\left(\frac{\partial V}{\partial z}\right)^{2}}
$$

The equation of Richardson Number (1) is composed of two fractions multiplied in the numerator, the first fraction being the gravitational acceleration force in its numerator $(\mathrm{g})$ and the main potential virtual temperature in the denominator $(\theta)$; the second fraction in the numerator is represented by the partial derivative $(\partial)$ of the main potential virtual temperature $(\theta)$ in relation to the vertical coordinate $(z)$. In the denominator of the equation of Richardson Number is the partial derivative from the main horizontal wind (V) in relation to the vertical coordinate (z), and is raised to 2 . Therefore, the lower the Richardson Number, the greater the possibility of a gravitational wave with a larger non-dimensional amplitude, that is, the more severe and extensive the occurrence of CAT.

Willians (2017) presents computational models resulting from observations of occurrences of Clear Air Turbulence. One of the explanations is the Coriolis Force, a force that deflects the normal flow of the winds caused by gravity and centrifugal force of the Earth's rotation, in the model it is considered the Rossby Number (2) which is an advective proportion of the Coriolis Force (COOPER et al, 2004).

$$
R o \cong \frac{|V \cdot \nabla V|}{\mathrm{f}|\mathrm{V}|}
$$

In formula (2), the Rossby Number is approximately equal to the numerator of the absolute value of the main horizontal wind multiplied by the gradient of the main horizontal wind, the denominator is placed in function ( $f$ ) of the absolute value of the main horizontal wind. Equation 3 defines the total time for flight delays on account of CAT through the sum of the delays for FL change and number of CAT observations, $\mathrm{i}=$ number of flight level changes.

$$
K=\sum_{i=1}^{n} k i
$$


Increased environmental awareness and global problems have led to a shift in focus from studies of emissions from aircraft engines. The main concern was the identification of the contribution of aeronautical emissions to climate change and the reduction of the ozone layer. Emissions from aviation account for about $3.5 \%$ of the contribution of human activities to global warming by burning fossil fuels. ANAC says that the $\mathrm{CO} 2$ emissions generated by air transport corresponds to $2 \%$ of the global volume. But they should grow to $5-6 \%$ by 2050 seconds (IPCC Report, 1999).

Currently, the main obstacle to more effective action on the problems caused by aeronautical emissions is the lack of scientific information. The most important initiatives aiming to fill this gap are developed by the European Union and the International Civil Aviation Organization (ICAO). The main gases and particles that make up the emissions are, carbon dioxide ( $\mathrm{CO} 2$ ), oxides of nitrogen (NOx), oxides of sulfur (SOx), water vapor and smoke. Smoke and aerosol emissions from aircraft are not significant when compared to other sources. ICAO studies solutions to mitigate the impacts of emissions. Potential solutions are formulated in three distinct areas: innovative technologies, operational measures and economic instruments.

\section{$\mathrm{CO}_{2}$ Calculation Methods}

According to Timmis et al, (2015), the anthropogenic production of $\mathrm{CO}_{2}$ (carbon dioxide) is considered as an effect of industrial and technological evolution. In addition, $\mathrm{CO}_{2}$ has been mentioned as the component that influences the greenhouse effect, which is the cause of global warming. And today, the burning of fossil fuels used in electric power generation and by means of transportation is considered the main source of $\mathrm{CO}_{2}$ (STROGENA et al., 2016). In aviation, 85\% of the fuel used is fossil. Only in 1992, approximately 514 million tons of aviation fuel were burned (WILLIAMS et al, 2016).

The Intergovernmental Panel on Climate Change (IPCC) developed two methodologies for calculating $\mathrm{CO} 2$ emissions, top-down and bottom-up methods. The top-down method, which is more widespread due to its greater data reliability, considers only $\mathrm{CO} 2$ emissions based on production and energy consumption data, without detailing how this energy is consumed. On the other hand, the bottom-up methodology will consider the type of fuel burning, the technology employed in the process, the mileage traveled and the total fleet, as well as other detailed information that is not always available (IPCC, 1999).

The bottom-up methodology is the interconnection of system data to move towards more complex systems. Transforming the original systems into subsystems of a larger final system at each step. A bottomup processing is a type of information processing based on input data from the medium to which the system belongs to form a perception. In a bottom-up approach the basic elements are initially described in detail. The elements are associated to form a larger subsystem, which can then be associated with other elements at many other levels, eventually until it completes the higher level of the target system. This strategy resembles a 'seed' model, to start small with basic elements and grow along associations (OLSEN et al, 2013). 


\section{METHODOLOGY}

From the statistical database of ANAC (2016b) it was possible to register all regular and non-regular flights made by Brazilian and international airlines that operate with origin or that has as a final destination a Brazilian airport. The data was scaled using Microsoft Excel 2016 ${ }^{\mathrm{TM}}$ Software. Were excluded from the model flights that have routes that at some time or in which in their totality do not pass through the area of Clear Air Turbulence delimited horizontally or vertically, as shown in item 3.1. Also, were excluded from the model: International airlines; Flights that were not carried out between the months of May to September; Nonscheduled flights; and Flights that were not operated with the Airbus A320 and Boeing 737 aircraft.

Table 2 shows the data obtained as inputs from the ANAC (2016b) statistical database for flights, as well as the Fiaco et al, (2016) methodology to delimit the CAT area, as well as the bottom-up of ICAO (2015) for the calculation of $\mathrm{CO} 2$ emissions. The generated outputs are for calculations of flight distance in and out of the CAT area, flight scheduling, CO2 emission calculation with and without CAT, and with bypassing. Variables were inserted to complete the model so that the calculations could be completed. These variables are based on the observation of the repetitive operations plan directory of the Brazilian Air Navigation Management Center (CGNA).

Table 2: List of inputs and output data for the proposed model.

\begin{tabular}{|l|l|l|l|}
\hline Inputs (ANAC, 2016b) & Inputs (ICAO, 2015) & $\begin{array}{l}\text { Variables } \\
\text { (ANMG) }\end{array}$ & Outputs \\
\hline $\begin{array}{l}\text { Origin and destiny Airport (AND); Airlines; Year and } \\
\text { month; } \sum \text { seats offer; } \Sigma \text { Passagers (PAX) paid and free; }\end{array}$ & $\begin{array}{l}\text { Aircraft type; } \\
\text { CO2/PAX; }\end{array}$ & $\begin{array}{l}\sum \text { CO2 Total Issued } \\
\text { Flight / Pax; }\end{array}$ \\
\hline- & $\begin{array}{l}\text { Distance of flight in } \\
\text { nautical miles; }\end{array}$ & $\begin{array}{l}\text { Distance in } \\
\text { kilometers; }\end{array}$ \\
\hline- & Flight time in minutes; & $\begin{array}{l}\text { Cruise Flight } \\
\text { Level }\end{array}$ & $\begin{array}{l}\text { Aerodynamic Speed } \\
\text { (km / hr); }\end{array}$ \\
\hline$\Sigma$ Paid and free cargo & $\begin{array}{l}\text { Fuel estimated for } \\
\text { consumption in step; }\end{array}$ & - & Payload \\
\hline
\end{tabular}

The items organized below explain the methodology used in this work.

\section{CAT Area Delimitation}

To find the area of highest occurrence of Clear Air Turbulence, we chose the Forecast Model presented by Pritchett et al. (2003) which provides an appreciation of the atmosphere conditions. From the research of Barros and Balero (2013), the research period was delimited between May 1 and September 30 as late fall, covering the entire winter period and early spring. Once during the autumn and winter when there is the evolution of the cold front over the warm front, indicated by the appearance of cirrus clouds.

The years of research were determined by the availability of the SIGWX charts in the meteorological database of the REDEMET portal, being established between the years of 2010 and 2013. A total of 2,448 charts corresponding to the significant prognosis of the weather for 612 days were analyzed, the charts were tabulated and organized in folders considering as nomenclature VALID (HOUR) UTC (DAY / MONTH / YEAR) and FL250-630.

The softwares Global Mapper $13^{\mathrm{TM}}$ and Blue Marble ${ }^{\mathrm{TM}}$ were used for image analysis because these are tools that uses Geographic Information Systems (GIS) and Image Processing (PDI) technologies. To delimit 
the Brazilian Airspace, the nine ENR (Enroutes Charts) charts were downloaded, available on May 3, 2015, with the last update of the information on March 5, 2015.

Using the Global Mapper13 ${ }^{\mathrm{TM}}$, 410 SIGWX charts were analyzed, which is the CAT Occurrence Quantity between 2010-2013, as shown in Table 2. To find out which area has the highest occurrence of Clear Sky Turbulence it was observed in which area the vertices Of CAT demarcations overlap more between SIGWX. The area found exceeds the limits of the Brazilian Airspace, its main extremities are to the upper end, lateral in the Atlantic Ocean, and lateral in the boundary of the Brazilian Airspace with the CTR (Control Zone) Paso de Los Libres, Argentina.

\section{Escalating the flight plan}

During the project two calculations were made to find the Aerodynamic Speed (VA). The first was a division of the airspeed filled on the flight plan by the estimated distance of the flight, obtained from ANAC (2016b). Equation 4 deals with the definition of VA change caused by the change of flight level (FL) to the deviation of the aircraft.

$$
V A=\left[\left(\frac{V I .2}{100}\right) \cdot\left(\frac{F L}{10}\right)\right]+V I
$$

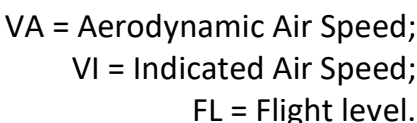

The payload is needed to find the quantity of $\mathrm{CO} 2$ emitted per km flown, found in formula 5.

$$
\begin{aligned}
& U L=\frac{\sum P L+\sum F L+(R P K \times 75)}{(Q T O \times F D)} \\
& \text { (5) } \\
& \mathrm{UL}=\text { Payload carried on the route; } \\
& \mathrm{PL}=\text { Paid freight carried }(\mathrm{kg}) \text {; } \\
& \mathrm{FL}=\text { Free freight carried }(\mathrm{kg}) \text {; } \\
& \mathrm{RPK}=\text { Sum of the multiplication of the number of pax by the distance of the flight; } \\
& \text { QTO = Number of departures; } \\
& \mathrm{FD}=\text { Flight distance (kilometer). }
\end{aligned}
$$

$\mathrm{CO} 2$ is calculated as demonstrated by equation 6 per kilometer traveled in flight by varying the amount of fuel supplied in pounds. The ICAO (2015) presents the constant 3,165 for the calculation of CO2 emission for aircraft of this model.

$$
\frac{C O 2}{k M}=\frac{\text { (Fuel Quantity in Step } \times 0,453592) \times 3,165}{F D}
$$

Fuel Quantity in Step = Estimated fuel to be spent in step (ICAO input).

\section{Model for calculating $\mathrm{CO} 2$ emissions with and without the CAT, and making a deviation}

Equation 7 identifies the $\mathrm{CO} 2$ equivalence per kilometer divided by the kilogram of the transported payload. Three scenarios were used to determine CO2 / KM / UL: under normal conditions; flight emissions within a turbulence area of its clearing (sum of time and consumption of flights outside CAT) and within CAT; and finally, the calculation of the time and fuel consumption for the aircraft to make a change in its level of 
flight (original flight level minus flight level outside CAT vertical area). To find the CO2 / KM / UL value under normal conditions, flights and equations 4,5 and 6 were used.

$$
\text { Equivalência CO2 por } \mathrm{kg} \text { transportado }=\frac{\mathrm{CO} / \mathrm{KM}}{U L}
$$

For the calculation of $\mathrm{CO} 2$ / KM / UL, the horizontal restriction coordinates of the CAT area were required. Other necessary coordinates are from the airports of origin and arrival. The equation to find the distance between two geodesic points is given by equation 8 .

$$
\begin{array}{r}
\text { Dist.CAT }=6371 \times A \operatorname{COS}((\cos (\pi \times(90-\text { Lat } 1) / 180) x \cos (\pi \times(90-\text { Lat } 0) / \\
180))(\operatorname{sen}(\pi \times(90-\operatorname{Lat} 1) / 180) \times \operatorname{sen}(\pi \times(90-\text { Lat } 0) / 180)) \times \cos (\pi \times(\text { Long } 0- \\
\text { Long } 1) / 180)) / 1,852
\end{array}
$$

Lat0 e Long 0 = Latitude and Longitude given by the constraint of the coordinate given by the CAT; Lat1 e Long 1 = Latitude and Longitude for the airport of origin.

The aircraft speed in CAT was obtained from the reference of Fiaco et al. (2016) where there is a loss of $10 \%$ of Aerodynamic Speed. Then, the speed in CAT was found from the difference between the original speed and the original speed decreased by $10 \%$. The time of flight in CAT (Time FL CAT) was found with the result of equation 9.

$$
\text { Tempo FL CAT }=\text { ABS ((Dist.CAT/Veloc.CAT })+(\text { Dist.FCAT/Veloc. }) \times 60
$$

ABS = absolute;

Veloc.CAT = Aerodynamic speed within CAT; Dist.FCAT $=$ Distance flown outside the CAT area; Veloc. = Aerodynamic speed.

To find the values referring to the calculation with the deviation is used the abstracted aerodynamic speed of $55.56 \mathrm{~km} / \mathrm{hr}$ as also given by the Fiaco et al. (2016), this value corresponds to the deceleration of the aircraft during the descent to not exceed its maximum structure speed. In this model it was considered that the aircraft were at flight level of 36 thousand feet (FL 360), as observed in the CENIPA directory, and with a change to altitude 26 thousand feet, observing CAT vertical restraints. To find the distance traveled in the descent was considered 0.15 as time in decimal of descent multiplied by the descent speed of the aircraft. The equation 9 was used to calculate the time during the CAT condition. The analysed flights are from the following airports and are the flights with more incidence during the the time with CAT presence: Brasília (SBBR); Curitiba (SBCT); Rio de Janeiro - Galeão (SBGL); e São Paulo - Congonhas (SBSP).

\section{RESULTS}

\section{CAT Area Delimitation}

The upper end is near the boundary of Curitiba FIR with Atlântico FIR, at coordinates $29^{\circ} 43$ '08 "S $047^{\circ} 03^{\prime} 25^{\prime \prime} \mathrm{W}$; at the lateral end in the Atlantic Ocean it is at $31^{\circ} 59^{\prime} 05^{\circ} \mathrm{S} 043^{\circ} 47^{\prime} 9$ "W; and finally, in the boundary of the Brazilian Airspace with the Argentinean's at coordinates $29^{\circ} 13$ '26 "S $056^{\circ} 39^{\prime} 3^{\prime \prime} \mathrm{W}$. The perimeter of the area found is 5,313.7 nautical miles.

To tabulate the results of sums and averages of the occurrences of Clear Air Turbulence it was sorted by Year / Month / Date and assigned the value 1 for the time of the forecast of occurrence of CAT, per day was added the amount of prediction times and if on the day, the CAT was assigned the attribute 1. For each 
CAT forecast time, the MIN attribute with the predicted Minimum FL and MAX for the predicted Maximum FL was set. Table 1 shows the tabulation results by summing the CAT event between SIGWX times, 4 prognoses per day at Universal Time Coordinated (0, 6, 12 and 18 UTC), and 12 UTC shows 116 occurrences followed by 18 UTC with 104 occurrences.

For the delimitation of the area of occurrence of Clear Air Turbulence, the coordinates already mentioned in the previous paragraphs of this item in the Global Maker software were arranged, where after the georeferencing of the map, the shapefile with the area was superimposed on the Google Earth software so that It would be possible to overlap routes that are subject to interference from the CAT. After the overlapping of the routes, it was possible to measure the distance that each aircraft enroute, travels within the Clear Air Turbulence area, to later calculate the increase in the fuel consumption of the aircraft, and consequently the increase of the emission of CO2. Figure 3 exposes the image taken from Google Earth with the delimitation of the area of occurrence of Clear Air Turbulence, and the layout of the affected routes.

The affected routes are from the following airports: Aruba (TNCA); Asunción (SGAS); Belo Horizonte - Confins (SBCF); Belo Horizonte - Pampulha (SBBH); Curitiba (SBCY); Bogota (SKBO); Brasília (SBBR); Buenos Aires (SAEZ); Cabo Frio (SBCB); Caldas Novas (SBCN); Campinas (SBKP); Campo Grande (SBCG); Cuiabá (SBCY); Curitiba (SBCT); Goiânia (SBGO); Londrina (SBLO); Maceió (SBMO); Manaus (SBEG); Maringá (SBMG); Montevideo (SUMU); Porto Seguro (SBPS); Recife (SBRF); Rio de Janeiro - Galeão (SBGL); Rio de Janeiro Santos Dumont (SBRJ); Salvador (SBSV); Santiago do Chile (SCEL); São Paulo - Congonhas (SBSP); São Paulo Guarulhos (SBGR); Temuco (SCTC); and Vitória (SBVT).

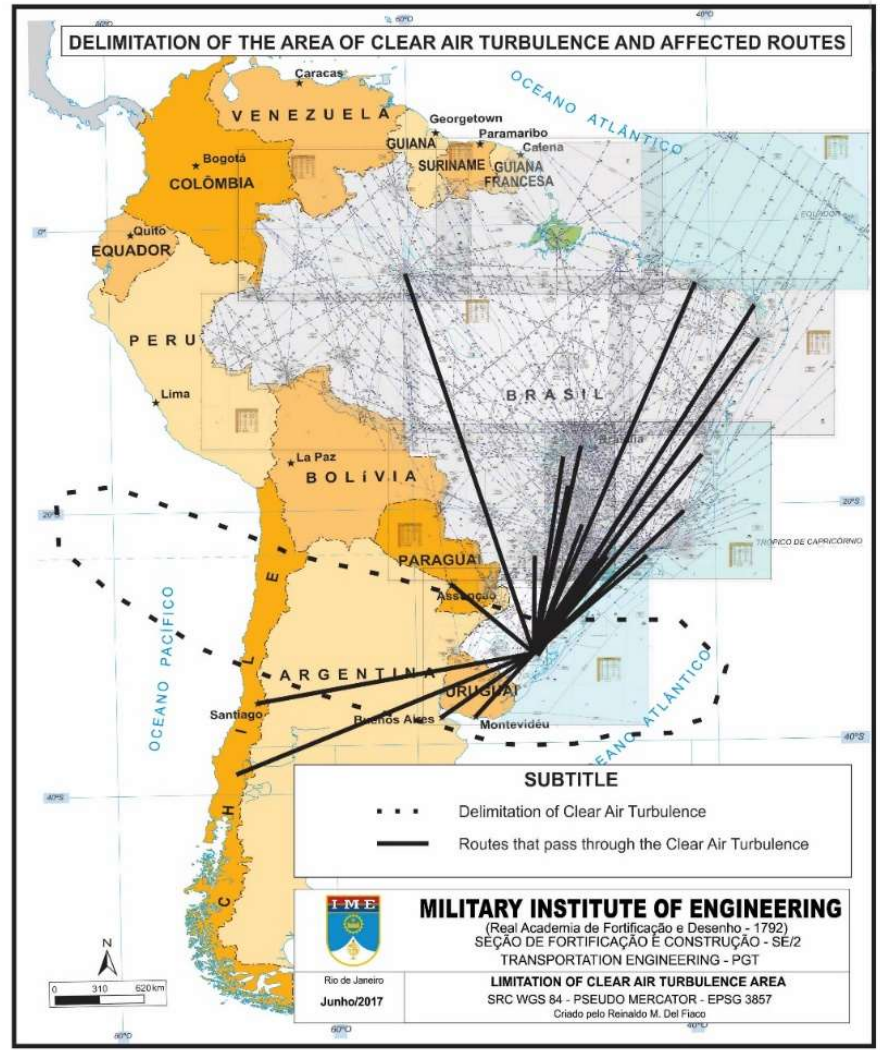

Figure 3: Delimitation of the area of occurrence of Clear Air Turbulence and affected routes. 


\section{Calculation of $\mathrm{CO} 2$ emission with and without the CAT, and effecting deviation}

Tables 3, 4, 5 and 6 presents the results regarding CO2 Emissions, considering and disregarding CAT, as well as using route deviation. Table 3 shows that for the routes originating from Domestic Airports, studies of the 737 aircraft, which, when performing the deviation from CAT, there is a decrease in the fuel consumption and as a result, there is a decrease of $4.7 \%$ in emissions Of $\mathrm{CO} 2$, when compared to the values found by CAT. Normal conditions occur at altitudes where there is no influence of CAT. Table 4 shows that, for routes originating from National Airports, studies of the aircraft 320, which when performing the CAT deviation, there is a decrease in fuel consumption, and as a result, there is a decrease of $6.2 \%$ in Emissions, when compared to the values found by CAT.

Table 3: $\mathrm{CO}_{2}$ Emissions for Aircraft 737 with Origin at National Airports.

\begin{tabular}{|c|c|c|c|c|c|c|}
\hline Source & Normal Co & ition & With CAT & & Deviation & m CAT \\
\hline Aircraft 737 & AVERAGE & TOTAL & AVERAGE & Aircraft 737 & AVERAGE & TOTAL \\
\hline Useful load (Kg) & 8968,27 & 753334,28 & 8968,27 & Useful load (Kg) & 8968,27 & 753334,28 \\
\hline Distance flown (Km) & 1998,80 & 173472,58 & 1998,80 & Distance flown (Km) & 1998,80 & 173472,58 \\
\hline Flight time (min) & 181,72 & 15628,00 & 191,85 & Flight time (min) & 181,72 & 15628,00 \\
\hline CO2/PAX/KM & 11,19 & 940,12 & 11,78 & CO2/PAX/KM & 11,19 & 940,12 \\
\hline $\mathrm{CO} 2$ by $\mathrm{Kg}$ transported & 0,0132 & 1,1066 & 0,0139 & CO2 by Kg transported & 0,0132 & 1,1066 \\
\hline
\end{tabular}

Table 4: CO2 Emissions for Aircraft 320 with Origin at National Airports.

\begin{tabular}{|l|l|l|l|l|l|l|}
\hline Source & \multicolumn{2}{|l|}{ Normal Condition } & With CAT & \multicolumn{2}{l|}{ Deviation from CAT } \\
\hline Aircraft 320 & AVERAGE & TOTAL & AVERAGE & Aircraft 320 & AVERAGE & TOTAL \\
\hline Useful load $(\mathrm{Kg})$ & 14422,24 & 966289,83 & 14422,24 & Useful load $(\mathrm{Kg})$ & 14422,24 & 966289,83 \\
\hline Distance flown (Km) & 1769,02 & 120293,33 & 1769,02 & Distance flown $(\mathrm{Km})$ & 1769,02 & 120293,33 \\
\hline Flight time $(\mathrm{min})$ & 164,57 & 10944,00 & 168,65 & Flight time $(\mathrm{min})$ & 164,57 & 10944,00 \\
\hline CO2/PAX/KM & 12,84 & 873,28 & 13,68 & CO2/PAX/KM & 12,84 & 873,28 \\
\hline CO2 by Kg transported & 0,0382 & 2,5182 & 0,0418 & CO2 by Kg transported & 0,0382 & 2,5182 \\
\hline
\end{tabular}

Table 5: CO2 Emissions for Aircraft 737 with Origin at International Airports.

\begin{tabular}{|l|l|l|l|l|l|l|}
\hline Source & \multicolumn{2}{|l|}{ Normal Condition } & With CAT & \multicolumn{2}{l|}{ Deviation from CAT } \\
\hline Aircraft 737 & AVERAGE & TOTAL & AVERAGE & TOTAL & AVERAGE & TOTAL \\
\hline Useful load $(\mathrm{Kg})$ & 8395,77 & 705244,47 & 8395,77 & 705244,47 & 8395,77 & 705244,47 \\
\hline Distance flown (Km) & 2002,14 & 3840015,00 & 2002,14 & 3840015,00 & 2002,14 & 3840015,00 \\
\hline Flight time (min) & 180,45 & 15158,00 & 181,20 & 15220,79 & 181,22 & 15222,87 \\
\hline CO2/PAX/KM & 11,04 & 927,47 & 11,10 & 932,21 & 11,10 & 932,41 \\
\hline CO2 by Kg transported & 0,0140 & 1,1790 & 0,0141 & 1,1849 & 0,0141 & 1,1849 \\
\hline
\end{tabular}

Table 6: CO2 Emissions for 320 Aircraft with Origin in International Airports.

\begin{tabular}{|l|l|l|l|l|l|l|}
\hline Source & \multicolumn{2}{|l|}{ Normal Condition } & With CAT & \multicolumn{2}{l|}{ Deviation from CAT } \\
\hline Aircraft 737 & AVERAGE & TOTAL & AVERAGE & TOTAL & AVERAGE & TOTAL \\
\hline Useful load $(\mathrm{Kg})$ & 10900,43 & 730328,74 & 10900,43 & 730328,74 & 10900,43 & 730328,74 \\
\hline Distance flown $(\mathrm{Km})$ & 1971,34 & 136022,55 & 1971,34 & 136022,55 & 1971,34 & 136022,55 \\
\hline Flight time $(\mathrm{min})$ & 176,99 & 12212,00 & 177,74 & 12264,03 & 177,78 & 12267,02 \\
\hline CO2/PAX/KM & 11,78 & 789,28 & 11,84 & 793,29 & 11,86 & 794,76 \\
\hline CO2 by Kg transported & 0,0126 & 0,8413 & 0,0126 & 0,8458 & 0,0127 & 0,8483 \\
\hline
\end{tabular}

Table 5 shows that for routes originating from International Airports, studies of aircraft 737, that it is not feasible to carry out CAT diversion, since Airports studied are within the perimeter of the CAT, the deviation does not result in decrease of $\mathrm{CO} 2$ emissions. Table 6 shows that for routes originating from International Airports, studies of aircraft 320, that it is not feasible to perform CAT diversion, since the airports studied are within the perimeter of the CAT, the deviation does not result in reduction of the 
emissions Of $\mathrm{CO} 2$. In the case of Aircraft 320 , there is a $0.29 \%$ increase in $\mathrm{CO} 2$ emissions if route deviation is used.

\section{CONCLUSIONS}

The analysis performed in this study shows that there is an increase in $\mathrm{CO} 2$ emissions when an aircraft reaches compatible altitude within the Clear Air Turbulence area. It can also be inferred that the presented option, which traces an alternative route diverting from the CAT area, is only representative when the routes begin outside the area of influence of CAT, since when starting from within the CAT area, the flight ends up suffering influence from CAT at first and later of the deviation of route.

Analyzing Tables 3 and 4, which appear in Chapter 4 of this article, the total winged distance of the aircraft to the aircraft 320 obtained a total winged distance $30 \%$ greater than the aircraft 737 . The payload carried by the aircraft 320 was $22 \%$ higher than that carried by aircraft 737 . This explains the $\mathrm{CO} 2$ emission value of aircraft 320 on routes originating from national airports.

Analyzing Tables 5 and 6, which appear in Chapter 4 of this article, the total distance flown is $180 \%$ greater in the aircraft 737 than in the aircraft 320, which characterizes a larger number of flights performed, while the transported payload does not have such a significant variation, with its variation at $3.44 \%$. This explains the value of $\mathrm{CO} 2$ emissions being greater on 737 aircraft, on routes from international airports, located in the CAT area. However, it should be noted that Tables 3 and 4 demonstrate the efficiency of the CAT deviation for flights from domestic airports not located within the CAT area. While Tables 5 and 6 show that for flights with departures within the CAT area, deviation does not generate efficiency to reduce $\mathrm{CO} 2$ emissions.

Operational measures represent a major opportunity to reduce emissions. The adoption of the new airspace communication and management system (CNS/ATM) and the modernization of the aviation meteorological website (redemet.aer.mil.br) allows the optimization of the use of routes and reduction of fuel consumption. Another proposed alternative is for airlines to offer users the option to purchase carbon credits at the time of airfare purchase, thus adding green marketing, as well as promoting environmental measures relevant to the ecosystem.

\section{REFERÊNCIAS}

ANAC. Agência Nacional de Aviação Civil. Base de dados completa, subdividida por ano. Ano 2016. Brasília: Agência Nacional de Aviação Civil, 2016 b.

ANAC. Agência Nacional de Aviação Civil. Páginas Temáticas, Meio Ambiente: Aviação Civil Internacional e Mudanças Climáticas. Brasília: Agência Nacional de Aviação Civil, 2016a.

BARROS, J. R.; BALERO, J. C. S.. A influência do Clima e do Tempo do Centro-Oeste do Brasil nas Condições de Voo na Região. Revista de Geografia da UEG, v.1, n.25, 2013.
BRASIL. Manual de Centros Meteorológicos. MA 105-12: Portaria DECEA n 134/SDOP. Ministério da Defesa. Departamento de Controle do Espaço Aéreo, 2013.

COPPER, M. D.; PHILLIPS, R. A.. Exploratory analysis of the safety climate and safety behavior relationship. Journal of Safety Research, v.35, n.5, p.497-512, 2004. DOI: http://doi.org/10.1016/j.jsr.2004.08.004

FAA. Federal Aviation Administration. A National Vision Statement, Framework for Goals and Recommended Actions. Aviation and the Environment, 2004. 
FIACO, R. M. D.; ALMEIDA, P. R. V.; SILVA, P. C. M..

Temporary Change of Aeronautical Routes in the Area of Possible Occurrence of Clear Air Turbulence. In: INTERNATIONAL CONFERENCE OF THE SYSTEM DYNAMICS SOCIETY, 34. Anais. v.34, n.1, 2016. DOI: http://doi.org/10.13140/RG.2.1.2791.7047

IPCC. Intergovernmental Panel on Climate Change. Aviation and The Global Atmosphere: A special report of IPCC Working Groups I and III. Cambridge: Cambridge University Press, 1999

LYONS, R. M; PANOFSKY, H. A.; WOLLASTON, S.. The critical Richardson Number and its implications for cast problems. Journal off applied meteorology, v.3, n.1, 1963. DOI: http://doi.org/10.1175/1520-0450(1964)003

OLSEN, S. C.; WUEBBLES, D. J.; OWEN, B.. Comparison of global 3-D aviation emissions datasets. Tmospheric Chemistry and Physics, v.13, n.1, 2013. DOI: http://doi.org/10.5194/acp-13-429-2013

PRITCHETT, A. R.; VAN PAASSEEN, M. M.; WIELAND, F. P.; Johnson, E. N.. Aerospace Vehicle and Air Traffic Simulation. In: CONFERENCE APPLIED SYSTEM SIMULATION. Anais. 2003. DOI: http://doi.org/10.1007/978-1-4419-9218-5 16

STROGENA, B.; BELLA, K.; BREUNIGC, H.; ZILBERMANA, D.. Environmental, public health, and safety assessment of fuel pipelines and other freight transportation modes. Applied Energy, v.171, p.266-276, 2016. DOI: http://doi.org/10.1016/j.apenergy.2016.02.059
TALAIA, M. A. R.; FERNANDES, R.. Diagnóstico de Vento de uma Região Usando uma Carta Meteorológica de Superfície. ENCONTRO NACIONAL E CONGRESSO INTERNACIONAL DE RISCOS, 5, 1. Anais. 2009.

TIMMIS, A. J.; HODZIC, A.; KOH, L.; BONNER, M.; SOUTIS, C.; SCHAFER, A. W.; DRAY, L.. Environmental impact assessment of aviation emission reduction through the implementation of composite materials. Int J Life Cycle Assess, v.20, n.2, p.233-243, 2015. DOI: http://doi.org/10.1007/s11367-014$\underline{0824-0}$

WILLIAMS, P. D.; JOSHI, M. M.. Clear-Air Turbulence in a Changing Climate. Aviation Turbulence, p.465-480, 2016. DOI: http://doi.org/10.1007/978-3-319-23630-8 23

WILLIAMS, P. D.; JOSHI, M. M.. Intensification of Winter Transatlantic Aviation Turbulence in Response to Climate Change. Macmillan Publishers Limited, Londres, v,3, p.644648, 2013. DOI: http://doi.org/10.1038/nclimate1866

WILLIAMS, P. D.. Increased light, moderate, and severe clear-air turbulence in response to climate change. Advances in Atmospheric Sciences, v.34, n.5, p.576-586, 2017. DOI: http://doi.org/10.1007/s00376-017-6268-2

CAOA, Z.; SHENA, L.; ZHAOA, J.; LIUA, L.; ZHONGA, S.; SUNA, Y.; YANGA, Y.. Toward a better practice for estimating the $\mathrm{CO} 2$ emission factors of cement production. Journal of Cleaner Production, v.139, p.527-539, 2016. DOI: http://doi.org/10.1016/j.jclepro.2016.08.070

A CBPC - Companhia Brasileira de Produção Científica (CNPJ: 11.221.422/0001-03) detém os direitos materiais desta publicação. Os direitos referem-se à publicação do trabalho em qualquer parte do mundo, incluindo os direitos às renovações, expansões e disseminações da contribuição, bem como outros direitos subsidiários. Todos os trabalhos publicados eletronicamente poderão posteriormente ser publicados em coletâneas impressas sob coordenação da Sustenere Publishing, da Companhia Brasileira de Produção Científica e seus parceiros autorizados. Os (as) autores (as) preservam os direitos autorais, mas não tem permissão para a publicação da contribuição em outro meio, impresso ou digital, em português ou em tradução. 